Volume 04 Issue 03 March 2021

DOI: 10.47191/ijsshr/v4-i3-02, Impact factor-5.586

Page No : 233-237

\title{
Absurd Sensationalism, Receded Morality in an Urban Family in the Vultures (1971)
}

\section{Perwez Alam}

Research Scholar, Department of English and Modern European Languages University of Lucknow, Lucknow

\begin{abstract}
A family is an organized system that connects all members together to exalt happiness and share grief to each other; they do not only help and hold shoulders with shoulders to strengthens family bonds and teach each other morality of life, respect and honour but also parents scold their sons and daughters for committing any mistakes to recuperate themselves in their career. Therefore, the sacred dignity of the family has been shattered nowadays in order to grab wealth and money. As Father has certain respect and honour at home similarly brothers and sisters have assured place in their parents " heart. The play The Vulture has exposed a middle class family in the urban set up that comprises many family members who can fulfil their house with happiness and pleasure but their thirst for wealth and money shattered their tranquil life. Pappa has accumulated property after so much works though he has grabbed his brother Sakharam's part who visits his home frequently to ask his part but his all efforts turned into dust and he is insulted by his nephews Ramakant and Umakant. They all are frustrated with the established system and they all started fighting for inheritance. They batter their own father for getting his hidden money though they all know that their demands and threat are transient, they will see the same satiation as they place their father at the moment. Their pursuit has no eternity as they show themselves that they have no goal; purposelessness, meaninglessness, disillusionment prevailed in their life. They sensationalize their arguments to quench their thirst and throw out their moral duty in respect of their father and family. For gaining absurd pursuit, they replicate the vulture like behaviour to kill their own father yet they are addicted to drinking and smoking and drugs, and keeping illicit relationship and outing at night for entertainment.
\end{abstract}

KEYWORDS: Morality, Property, Relationship, Addiction, Disillusionment and meaninglessness.

The play The Vulture is the realistic and artistic piece in Marathi language entitled Gidhade that depicts human instinct and their nature. The play is written in Marathi by Vijay Tendulkar that has been translated into English by Priya Adarkar. The play has makes Tendulkkar is one of the best Marathi literary playwrights who has given new direction to the play writing, growth of Marathi theatre that made him as distinguished model for other playwrights. He has applied Theatre of the Absurd in the play to demonstrate fragmentation in the organised society. The study of play replicates that the dialogues are broken; sentences are meaningless, disconnected thoughts and plot, no coherence for development of events that symbolize purposelessness, meaninglessness and disillusionment. Its essential and related information is quoted:

Gidhade (The Vulture), chronologically the next play to be produced (1970) and published (1971) after Mukabala, was actually written fourteen years before. The entirely different nature of the work underlines the astonishing range of Tendulkar ,s dramatic genius. After the first production of this play, Girish Karnard wrote that the staging of Gidhade could be compared to the blasting of a bomb in an otherwise complacent marketplace. (Banerjee Xii)

The central characters are the best elements in the play to explicate its core message and statement. There are mouth piece characters as Pappa is the head of the family who thought that his matured sons and daughter will protect and take care of him in his old age though he is corrupt and drunken man who grabbed his brother Sakharames property. His two sons Ramakant and Umakant have not been carrying out any worthy job to sustain their life in the city properly. Consequently, they always fight for property division and they abuse each other in low and mean language that demonstrate their receded morality, even they both and their sister Manik have planned to kill their father for getting rest of his wealth for they behave like the vulture in human shape that their life is meaningless and purposeless because their constant demands and gains are transient. On the other hand, Manik is his only daughter who gets up late and addicted to drinking and drug, similarly she outs frequently in the nights for entertaining in the clubs, and she has been enjoying live in relationship and becomes pregnant. Pappaes one bastard son Rajaninath who is a poet, his father appreciates him but he criticizes his father. The entire family is a perfect replica of middle class in the urban society that is constructed by Vijay Tendulkar in his outstanding play The Vulture.

They all can make their family happier and cheerful by sharing their sorrow and happiness rather than fighting and 


\section{Absurd Sensationalism, Receded Morality in an Urban Family in the Vultures (1971)}

complaining because they have everything except proper bond and understanding, it is mentioned, "Spending time together is one of the greatest gifts families can give to one another. Not only does quality time strengthen and build family bonds, but it also provides a sense of belonging and security for everyone in the family. In fact, research has shown that when families enjoy activities together, children not only learn important social skills but also have higher self-esteem" (Witmer Par. 1)

The play opens with great stage direction that is essence of dermatology; which has been experimented by the most of the playwrights as Mahesh Elkunchwar and Satish Alekar. Stage direction portrays the setting, motto, plight, coherence, clarity, engaging, time, action and characters that constitute an appreciable plot which contains symbolic lines as "Then the passageway is drowned in darkness. Light in the garage. Rajaninath is sitting writing. He suddenly starts and looks at the door. There is the noise of a corrugated iron gate opening. The noise of the wind continues. ... Then total silence". (Tendulkar 201). The lines signify the human beings" journey through the entire life where they see painful and anguished circumstances, happiness and joy, experience noise of the world for attaining livelihood and position that same sound buzz till they have enthusiasm but gradually that weakens their sense of energy and pursuits. Ultimately, eternal silence seizes them forever though they never prevent themselves from such heinous activities that snare them in unforgettable commitment that reduce their moral values and respect.

Rajaninath has written more than two absurd pages in the first Scene that postulates quite meaningful ideas that express importance of existence and decay. They have been spending their life as they adorn it with the beautiful ornament but with the passing of time, death will devour everything. He has delineated significance of death that cannot be stopped by anything; while they demand it to come and take away their breaths but it will not come. It signifies that death is inevitable that has certain time to come. Indeed, human beings are object to die any day but they do not restrain themselves depriving others and creating violence rather than keeping up moral values and humanity, and adopting meaningful goal.

Rajaninath: A death unattainable. Ungainable. Even by prayer.

Their time comes,

But their death does not come.

Not at home, but a hole in a tree

Where vultures lived

In the shapes of men. (Tendulkar 202 and 204)

Receded morality has been perceived in Manik ${ }^{e e}$ speech who has got up late in the morning and starting throwing out her hidden craving to Rama for calling her to wake up; she is matured girl now but no goal and hope except complaining against father and family members. As girl who should compete with male for acquiring success and dignity rather than wasting time and money sipping wine and lightening cigarette in the morning. As Indian culture prevailed that a person gets up and freshens up themselves first, and pray their god but Manik without freshening herself up started drinking and smoking. One of the important things is to be pointed to clarify the person who wishes such life style, dress and food that they are unable to afford. The same desire provokes the person to wash away from her straight path and carry out such tasks that lead to perilous effect and outcome. Her words symbolise her disintegration from her family, disillusionment and meaninglessness in her career.

Manik: (...Opens the bottle of the pills, takes one, drinks. Pulls at her cigarette)

The last two months, I have been dying for that latest necklace at Harivallabh's. But I can't bloody afford it! If I ask for money. No one"s got any. Just a matter of one thousand. But papa comes at me a fury if I even mention it. The old man's become senile since we divided the estate. As for Umya-that miser, that lickpenny! No use asking him, the bloody ruffian. (Tendulkar 207-208).

Obviously, circumstances and perturbed situation generally change a person's habit and morality because they long for certain thing but that brings different outcome as it results fragmentation, disintegration and anguish. In fact, Manik has revealed that Rama and her husband have tormented her in order to grab her property. After division their property that created division in their family. Even she blames her brother and Rama that they have given poison in her food to kill her but she did not eat that. She wakes day and night for keeping up herself alive. Same complicated circumstances have transformed her life style and morality that signify her existential crisis and loss of hope for integrity of the family because a simple life needs a lot of money to survive in the cities.

They all must perceive importance of morality that is only a great source for happiness and unification in the family and society rather than fighting for transient gains, as it has been described, "Moral Values are the worthy principles that one follows to distinguish the right from the wrong. These virtues are considered worthy in building up the character of an individual. Moral Value refers to the good virtues such as honesty, integrity, truthfulness, helpfulness, love, respectfulness, hard-work"(BDM Par. 1)

Is life is quite absurd in this transient world? Is well-organized family entirely broken in the cities due to division of property? Why are daughters and sons waiting for their old parents" death? Is love between parents and children changed with passing of time? Answer is very simple as Pappa has sacrificed all his comforts and rest to take care of his daughters and sons from their childhood with optimistic sense and understanding while they will be old and weak physically; their grown and successful sons 


\section{Absurd Sensationalism, Receded Morality in an Urban Family in the Vultures (1971)}

and daughters will look after them as they were taken care in their childhood but situation is entirely different. Ramakant tells a lot of immoral comments to his father who is not given proper breakfast and food. He does not only forwards all blames to his father but also his wife deals with him carelessly for arranging food and other services that is the utmost moral duty to carry on in their life.

Pappa: ... What's happened to my breakfast? ...

If you don't have it, you will starve us to death!...

He has ruined the whole business. But it's crime if I mention it! The other day, he raised flower vase to hit me. Going to kill me, he was! Die, rather! Drop in the ditch! I have just stopped talking him. ...

If I die, it will be release! They are all waiting for it. But I am your own father, after all! If I die, I will become a ghost. I will sit on your chest! I won"t let you enjoy a rupee of it. I earned it all. Now, these wolves, these bullies! ...

Hold your tongue! I have shared out my property with you pimps. So I become a burden, Have I? (Tendulkar 208-209, 211).

Aforementioned foreground dialogues symbolize that family relationship is a business. Parents have been taking cares of their children from childhood to adulthood and keeping up hopes from them for their old age caring. Consequently, their sons and daughters got their property. Then their parents become burden for them as Pappa and Ramakant have been cursing each other though they have the most sacred relationship as father and son. Due to property and wealth, a father demonstrates that he will come to revenge in the shape of ghost even he will die. On the other hand, Ramakant is under pressure of debt that"s why he blames his father that he is eating home without any work. Actually, Ramakant holds share in business property and Umakant has share in farming in Lonavla. Transaction of money from one person to another person is the replica of the transaction from love to enmity. The relationship has been solemnised respectfully and passionately while it has been shattered in the basis of land and property. In fact, human nature should not be changed for materialistic gain while they can procure happiness through family relationship and sharing.

Umakant and Ramakant have been abusing each other for not sharing family expenditure, Ramakan says that his brother is his bloody enemy because he is not spending money at home. Their offensive dialogues replicate that they all are much uncivilized persons. Vijay Tendulkar has used such common languages to show legitimacy of a middle class family how they fight for their trivial issues that postulate them immoral in urban societies. They both brothers are waiting for his father's death that is incredibly agonizing for sensitive persons. They forget that today their father is old , tomorrow they will be old similarly. So their fighting for wealth is exactly absurd pursuit that ultimately will vanish one day. As they discuss:

Pappa: Shut up your foul mouths, you scoundrels! Bury me, will you! Talk of burying me while I am alive, will you, you bastards?

Umakant: The whole town is shouting it! Didn't you two get drunk the other night? In that room at the Majestic Hall? And make scene.

Manik: An absolute lie! We did not! You are slandering us. Bloody beasts! You want to ruin me! You'd like to kill me! Umakant: We are going to slit her throat! That's why she goes into town daily... and falls round the idiot's...! And that worthless Hondur's only third- class Raja! (214-15).

Their language portrays absurd sensationalism and receded moralities that denigrate their respected image which is constructed by his father sweating his prolong effort. They abuse each other like they are enemy not family members. Using vicious word against own brothers and sisters is based on division of inheritance, transaction of money and bank balance. Do they measure their family members on money? So where they will find happiness and glory! Is money only source to quench their sensational desire and lust that they are addicted to in their present life. Definitely, they need money to survive in great cities but they cannot ask dignity of relationship because Pappa has certain distinction in the family where brothers have certain expectation and respect from each other. In the society, it is seen that a brother files a case against his own brother for claiming his part in the inheritance. Similarly, Umakant and Ramakant have been behaving to hurt his father and each other though they know that their pursuits is not eternal, after few years same situation will come to them.

Property dispute is very common in each house whether it be in rich or middle class family but it can be settled down by family agreement and mutual understanding, if there no agreement among family members that case never be solved by any courts as it is quoted, "A family settlement is a mutual agreement among family members, ordinarily made to completely prevent getting involved in court battles by splitting up the family property through mutual understanding among the family members." (Helpline Law par. 6)

Materialistic attitudes and yearning for grand life style that they do not afford in the city, which causes their prolong anguish. They do not want to share anything with their own brother whom they love so much once; situation has taken intensity for degrading morality and dignity of family that has been built by Pappa but his father is also corrupt, he has grabbed his own bother's property. His bother Sakharam has come to their home to claim his part but he has no respect at his home; his nephews try to offend 


\section{Absurd Sensationalism, Receded Morality in an Urban Family in the Vultures (1971)}

him and even push him from their home. Breach in relatives is obvious that frequently occurs at the most of houses but they should keep it up to the marked. What they think that using such sadistic language relieve them; no, the same hurting feeling will torment them also. They discuss each other and forward blames to their father yet every one of them is angry on each other. No one is ready to accept their own fault that replicate hopelessness, nothingness, meaninglessness and disillusionment. It also symbolizes that they have been suppressed by somewhere and someway. The writer has used so many Exclamation marks to sensationalize the dialogues as journalists have been using to grab attention, the playwright Vijay Tendulkar longed for audiences "e attention in The Vulture.

Ramamkant: Aha! No, no, no. Sorry, brother! I am extremely sorry. He's...y, know... our uncle! Father's brother! Our own uncle!

Umakant: Damn him. Our own. ...

Ramaknt. Let"s-let"s take him off the sofa. Before he ruins it. Put him down! It will get bloody dirty nothing, the sofa!

Rajaninath. Your hasband is not my bother! It humiliates me to call such low people my brothers! And such a corrupt man, my father. (Tendulkar 220, 223).

Vijay Tendulkar has talked about a middle class family which has everything to sustain themselves happily in the city as beautiful home, well-afforded washroom and bathroom, sofa and rooms but lack of integrity in the family members that vanish their peaceful circumstances and compassion from their family, even they want to kill their own father to grab his hidden amount. He has present human instinct like vulture in human shape who eat flesh rather than understand pain of the animal. Ramakant and Umakant and their sister Manik have tied their father with rope to kill him. He frequently requests them leave him alone but they all threaten to tell them other bank balance, fill the blank cheques to withdraw money as his father implores them not to hurt him.

Pappa: No! Never! You are devil, you pimp! You are going to kill me! You are going to murder me ... murder! I don"t want to die! Don"t want to! ...

Manik: Enough! Don't make such an unnecessary fuss, Pappa! It is only a tiny cut.

Pappa: You get away from me too, you she-devil! You are like the rest of them! You have plotted this. You are going to kill me! You are going to take my life. Murder me! You will rob what little money I have got left. (Tendulkar 219).

Killing a person is the great crime that is liable for life imprisonment or capital punishment, and intention of killing any relatives is anti-humanity and rights. If Ramakant and Umakant"s intention of harassment will be prevented, it will be destructive and disappointed for their family. As it is mentioned here, "The punishment for murder under India"s Penal Code is life imprisonment or death and the person is also liable to a fine." (Ahmad A. Murder)

Vijay Tendulkar has postulated sensual and illicit relationship that has been carried out by Manik even she becomes pregnant. Her brothers have blamed her in the beginning of the play The Vulture for her frequent outing in the night and late arrival at home. Each of them has not been keeping up certain job that makes them successful and competent in the competitive world; though they are addicted to drinking, smoking and drugs. So they fight for family property, even Manik is a girl who should work for her father, though she spends extraordinary money and ask from father. Due to her carelessness, she has no respect at home and spoiled her career and felt sorrow.

Ramakant: Oh, no, no! Not that, brother. Hear me. She is pregnant. If you want her fixed, put down the money. Cash down. Twenty thousands, what? More, if you like. Otherwise, bloody publicity! Uproar in the bloody newspapers! ... (Tendulkar 236).

The play The Vulture exposes the human nature like vulture in term of sharing wealth and property. As a vulture has no such sense to share flesh of the dead with partner that has taken any piece or not, but it chomp its hungry stomach. Killing an innocent man for grabbing his wealth and money, or quenching thirsty desire that is unquenchable for everyone a while. In fact, Umakant tries to transform family house in his name though did not divide it. As they both discuss:

Umakant: Will you transform this house to my name? Then I will redeem it. Ramakant: (Shouting) Brother, the house is my bloody share...

Umakant: Your share"s going into the Multani money lender"s throat! Are you going to change the house to my name? Tell me! (Tendulkar 254).

To sum up, the versatile playwright Vijay Tendulkar had expounded prevailed scenario of the middle class family in the city which has a great esteem and bond of all the members. The same family has broken down into fragmentation and adversity in order to grab property more than other and accumulate huge amounts for spending their desired life style though they have not been carrying up any worthy jobs. Therefore, doing nothing but having desire of grand life style in the city that cause great havoc and melancholy for them and vanish their worthiest property is love and compassion in the their life. Pappa is the chief protagonist who has sweated his utmost effort for accumulating money and wealth; he has thought that his wealth and sons will look after him in his old age but 


\section{Absurd Sensationalism, Receded Morality in an Urban Family in the Vultures (1971)}

his matured daughter and sons abuse him verbally, even they have planned to kill their father for getting his concealed bank balance. Essentially, division of the property has created division in the family yet Umakant and Ramakant fight each other and use derogatory languages that represent their immorality and absurd pursuits. Their behaviour and commitment symbolizes that they have been suppressed and marginalized which proposes meaninglessness, purposelessness. Indeed, they have placed their own father in such a position that they will meet same in the recent future. They failed to recuperate themselves and purify from drinking, smoking and drug, keep up family respect regarding cultural values, social responsibly and civilization.

\section{WORKS CITED}

1) Ahmad, Tariq. "Sentencing Guidelines: India". LIBRARY, Apr. 2014, www.loc.gov/law/help/sentencing-guidelines/india.php.

2) BDM International. Importance of Moral Values in Student's Life. 11 June 2019, https://medium.com/@seo_47773/importanceof-moral-values-in-students-life-6458a3102a78\#: :text=Moral\%20Values\%20are\%20the\%20worthy,\%2C\%20hard-work\%2C $\% 20$ etc.

3) Helpline Law. Property dispute between blood relations. Visit, Jan. 07, 2021, www.helplinelaw.com/real-estate-willsprobate-and-trust/PDBR/property- dispute-between-blood-relations.html.

4) Tendulkar, Vijay. "Introduction" Five Plays. Oxford University Press, New Delhi, 1992

5) -------. Five Plays. Oxford University Press, New Delhi, 1992.

6) Witmer, Denise. "How to Strengthen Family Bonds, Bring Your Family Closer and Build a Firm Foundation". Verywell family, March 04, 2020, www.verywellfamily.com/how-to-strengthen-your-familys-bond-ten-tips- 2609591. 